\title{
Study on Growth Effects of Major-Nutrients Composition to Banana Cultivation in Coastal Areas of Sindh, Pakistan
}

\author{
Shahmir Ali Kalhoro',2, Xuexuan Xu1 ${ }^{*}$, Amanullah Mahar ${ }^{3}$, Amjad Ali' ${ }^{3}$, Fahad Ali Kalhoro4, \\ Sohail Ahmed Otho5, Rab Nawaz Soomro6, Fayaz Ali3 , Zulfiqar Ali Baloch7 \\ ${ }^{1}$ Institute of Soil and Water Conservation, Northwest A\&F University, Yangling, China \\ ${ }^{2}$ Faculty of Agriculture, Lasbela University of Agriculture, Water \& Marine Sciences, Lasbela, Pakistan \\ ${ }^{3}$ College of Natural Resources and Environment, Northwest A\&F University, Yangling, China \\ ${ }^{4}$ Department of Plant Breeding \& Genetics, Sindh Agriculture University, Tando Jam, Pakistan \\ ${ }^{5}$ College of Plant Protection, Northwest A\&F University, Yangling, China \\ ${ }^{6}$ College of Animal Science and Technology, Northwest A\&F University, Yangling, China \\ ${ }^{7}$ College of Economics and Management Sciences, Northwest A\&F University, Yangling, China \\ Email: xuexuanxu@nwsuaf.edu.cn
}

Received 10 March 2015; accepted 21 April 2015; published 24 April 2015

Copyright () 2015 by authors and Scientific Research Publishing Inc.

This work is licensed under the Creative Commons Attribution International License (CC BY).

http://creativecommons.org/licenses/by/4.0/

(c) (i) Open Access

\section{Abstract}

The composition of major nutrients, i.e. nitrogen, phosphorus and potassium (NPK), is a critical factor in banana cultivation and also influences crop yield. This study was aimed to analyze the concentrations of NPK in different banana growing locations of coastal areas of Sindh, Pakistan. A total of 15 composite soil samples at the depth of $0-15$ and $15-30 \mathrm{~cm}$ and the same number of banana leaves were collected. The samples were analyzed for the concentration of $\mathrm{N}, \mathrm{P}, \mathrm{K}, \mathrm{Ca}, \mathrm{Mg}$, $\mathrm{Zn}, \mathrm{Mn}$ and $\mathrm{Cl}$ concentrations. Results showed that the surface and sub-surface soils of coastal areas were heavy in texture, non-saline, medium alkaline and moderately calcareous in nature. Medium to adequate in Organic Matter (OM), medium in total nitrogen, medium to optimum in available phosphorus, medium to high in exchangeable potassium and deficient in available zinc at both tested depths. The analysis of soluble anions indicated that the carbonates were absent and that chlorides were dominant as compared with bicarbonates. Nitrogen and zinc concentrations of banana leaves were below the critical level, whereas $\mathrm{P}, \mathrm{K}, \mathrm{Mn}$ and chloride ion concentration were above the critical levels. In addition, the relative percentages for $\mathrm{K}$, $\mathrm{Ca}$ and $\mathrm{Mg}$ were 57.72 to $61.72,19.05$ to 21.00 and 17.70 to 20.00 respectively.

${ }^{*}$ Corresponding author.

How to cite this paper: Kalhoro, S.A., Xu, X.X., Mahar, A., Ali, A., Kalhoro, F.A., Otho, S.A., Soomro, R.N., Ali, F. and Baloch, Z.A. (2015) Study on Growth Effects of Major-Nutrients Composition to Banana Cultivation in Coastal Areas of Sindh, Pakistan. American Journal of Plant Sciences, 6, 1003-1010. http://dx.doi.org/10.4236/ajps.2015.67106 
Keywords

Banana, Cultivation, Nutrients, Yield, Soil, Leaves

\section{Introduction}

Banana holds a high position in fruit and food crops of the tropical and sub-tropical regions. Being a cash crop of high value, it is a good source of income for growers, and its taste and high nutritional value keep it in high demand by consumers, throughout the year.

The world produces 42 million tons of bananas yearly [1]. Major banana growing counties are America, Brazil, Australia, Bangladesh, Philippines, etc. [2] [3]. In Pakistan, banana cultivation has shown a progressive increase over the time. In 1989, the area under banana cultivation was 23.5 thousand hectares and yielding 209 thousand tons.

Sindh is the leading banana growing province of Pakistan having $86.42 \%$ of total banana production [4]. Major banana growing districts of Sindh province are Hyderabad, Mirpurkhas, Badin, Thatta, Nawabshah, Nausharo Feroze, Khairpur, etc.

Banana requires more nutrients than any other commercially important crop that must be supplied through giving synthetic fertilizers to obtain optimum yields, as every crop requires all the essential nutrients in adequate quantity for active growth and food production. The macronutrients nitrogen, phosphorus, and potassium (NPK) are required in large quantities and soils are usually deficient of these nutrients.

Nitrogen is very critical for banana nutrition, because it is a component of various plant proteins. Nitrogen participates in photosynthesis through a series of enzyme reactions as well as being part of chlorophyll molecule.

Phosphorus is a part of nucleic acids, phospholipids, energy storing and transferring system in the plant. It is required in high concentration at the growing stages of roots and shoots.

Potassium is considered as the most important nutrient in banana cultivation, because it is required for at least 60 different enzymes evolved in plant growth. Potassium is not a constitution of any plant structure or organic compound, but it is essential in nearly all the biological processes needed to sustain plant life and catalyse important metabolic reaction such as respiration, photosynthesis, starch synthesis, regulation of stomata and regulation of nutrients and water intake [5].

Through the survey of the banana growing areas of Sindh province, it was observed that growers were not applying the required dose of the fertilizer to meet the nutrient requirement of the crop. Therefore, this study was conducted to analyze soil and plant leaf samples from the bananas growing areas of coastal region of Sindh province to assess the status of major nutrients in soil and plants. The concentrations of major nutrients were compared with agriculture soil standards and the equilibrium relationship among $\mathrm{K}, \mathrm{Ca}$ and $\mathrm{Mg}$ was characterized.

\section{Materials and Methods}

\subsection{Soil Sample Collection}

The study was conducted at privately owned different agricultural farms in coastal areas of Sindh Province. A total of 15 soil samples at the depth of $0-15$ and $15-30 \mathrm{~cm}$ including 15 banana leaves samples were collected randomly from the selected areas. A total $50 \mathrm{gm}$ soil was collected from four corners and one from centre then mixed together to get bulk sample. Soil and banana leaves samples were put in polyethylene plastic bags, labelled and preserved according to standard procedures. Soil samples were brought to laboratory on the same day and stored in the refrigerator at $4^{\circ} \mathrm{C}$ prior to analysis. Soil samples were sieved $2 \mathrm{~mm}$ using mechanical shaker. Analysis was carried out in the analytical labs in the Department of Soil Science, Sindh Agriculture University, Tando Jam, Sindh, Pakistan.

\subsection{Research Design}

The physicochemical properties of soil samples were analyzed i.e. soil texture, organic matter, $\mathrm{pH}, \mathrm{EC}$, lime 
$\left(\mathrm{CaCO}_{3}\right)$, carbonates, bicarbonates, macronutrients (NPK, $\mathrm{Ca}$ and $\mathrm{Mg}$ ) and micronutrient $(\mathrm{Zn})$.

Soil texture was determined using Hydrometer method [6]. $40 \mathrm{~g}$ air-dried soil $(2 \mathrm{~mm})$ was taken and $60 \mathrm{ml}$ of dispersing solution (Dissolve $40 \mathrm{~g}$ sodium hexametaphosphate $\left[\left(\mathrm{NaPO}_{3}\right)_{13}\right]$, and $10 \mathrm{~g}$ sodium carbonate $\left(\mathrm{Na}_{2} \mathrm{CO}_{3}\right)$ was added in DI water, and final volume was raised upto $1000 \mathrm{ml}$. The solution was shacked using orbital shaker (SCILOGEX Analog Orbital Shaker SK-O180-E) for 30 minutes. Then solution was transferred into $1000 \mathrm{ml}$ measuring cylinder and inserted hydrometer. Sample was stirred and noted first reading and left for 2 hrs for second reading. Soil texture was calculated using soil textural triangle.

$50 \mathrm{~g}$ air-dried soil $(<2 \mathrm{~mm})$ was taken and added $250 \mathrm{ml}$ DI water and put for vertical shaker (THZ, China) for $2 \mathrm{hrs}$. EC and pH reading was noted using $\mathrm{pH} / \mathrm{EC}$ Meter (2182A, Spectrum Technologies, Inc.)

Organic matter was determined using Walkley-Black method [7]. Weighed $1 \mathrm{~g}$ air-dry soil $(0.15 \mathrm{~mm})$ and added $10 \mathrm{ml} 1 \mathrm{~N}$ potassium dichromate then added $20 \mathrm{ml}$ concentrated $\mathrm{H}_{2} \mathrm{SO}_{4}$ using a dispenser, and swirl the beaker to mix the suspension, added $200 \mathrm{ml}$ Distil water, added $10 \mathrm{ml}$ concentrated $\mathrm{H}_{3} \mathrm{PO}_{4}$ and allow the mixture to cool, added $10-15$ drops diphenylamine indicator, titrate with $0.5 \mathrm{M}$ ferrous ammonium sulfate until the color changes from violet-blue to green. Prepared two blanks, containing all reagents but no soil, and treat them in exactly the same way as the soil suspensions Organic matter was calculated using formula.

Phosphorus was analyzed using Olsen techniques [8]. Exchangeable $\mathrm{K}, \mathrm{Ca}$ and $\mathrm{Mg}$ were determined by using flame photometer (Cole-Parmer Four-Element Flame Photometer, WU-02655-15).

$10 \mathrm{~g}$ air-dried soil $\left(<2 \mathrm{~mm}\right.$ ) was taken and put into a 250-ml flask, pour $50 \mathrm{ml} 1 \mathrm{~N} \mathrm{NH}_{4} \mathrm{OAc}$ solution (ratio 1:5), shacked for 30 minutes using reciprocal shaker (Model E5850) at $200-300 \mathrm{rpm}$, filter suspension using a Whatman No. 1 filter paper to exclude any soil particles, and brought the extract to a 50 -ml volume with $1 \mathrm{~N}$ $\mathrm{NH}_{4} \mathrm{OAc}$ solution. Readings were expressed in $\mathrm{mg} / \mathrm{kg}$.

Carbonate, bicarbonate and chlorides were determined using titration method. Pipette out $10-15 \mathrm{ml}$ soil saturation extract in a wide-mouthed porcelain crucible or a 150-ml Erlenmeyer flask, added 1 drop phenolphthalein indicator, If pink color develops, added $0.01 \mathrm{~N} \mathrm{H}_{2} \mathrm{SO}_{4}$ by a burette, drop by drop, until the color disappears, take the reading for carbonate, continue the titration with $0.01 \mathrm{~N} \mathrm{H}_{2} \mathrm{SO}_{4}$ after adding $2 \%$ drops $0.1 \%$ methyl orange indicator until the color turns to orange noted the reading for bicarbonate. Now for chlorides added $4 \%$ drops $5 \% \mathrm{~K}_{2} \mathrm{CrO}_{4}$ solution in sample and titrate against $0.01 \mathrm{~N} \mathrm{AgNO}_{3}$ until a permanent reddish-brown color appears.

Calcium carbonate was also analyzed using titration method. $1 \mathrm{~g}$ of air-dried soil $(0.15-\mathrm{mm})$ was taken into a 250-ml Erlenmeyer flask, added $10 \mathrm{ml} 1 \mathrm{~N} \mathrm{HCl}$ solution to the flask with a volumetric pipette, swirled and left the flask overnight, or heat to $50^{\circ} \mathrm{C}-60^{\circ} \mathrm{C}$, and let the flask cool, added $50-100 \mathrm{ml}$ DI water using a graduated cylinder, and add 2 - 3 drops phenolphthalein indicator, titrate with $1 \mathrm{~N} \mathrm{NaOH}$ solution while swirling the flask. Continue the titration until a faint pink color develops, and take the reading, $R$.

$0.5-1.0 \mathrm{~g}$ air dried and ground plant material $(0.15 \mathrm{~mm})$ into a $300-\mathrm{ml}$ calibrated digestion tube (or into a 150-ml conical flask), added $5 \mathrm{ml}$ concentrated $\mathrm{H}_{2} \mathrm{SO}_{4}$ (in the fume hood), and swirled carefully and then placed tubes in the rack, placed the tubes rack in the block-digester (or hot plate), and then place a glass funnel in the neck of the tubes, slowly increase temperature setting to about $145^{\circ} \mathrm{C}$ for 1 hour, added $5 \mathrm{ml}$ tri-acid mixtures and heat it to $240^{\circ} \mathrm{C}$ for to further 1 hour, and if possible, keep overnight to prevent excessive foaming, lift the tubes rack out of the block-digester, carefully place on a rack holder, and let tubes cool to room temperature, filter through Whatman No. 42 filter paper and bring to 50-ml volume, determined $\mathrm{Fe}, \mathrm{Mn}, \mathrm{Cu}, \mathrm{Zn}, \mathrm{Cd}, \mathrm{Ni}, \mathrm{Pb}, \mathrm{Co}$, and Cr using AAS (Varian Spectra AA 240, USA).

The study was conducted at private agricultural farms in the coastal areas of Sindh, Pakistan. 15 Soil (surface plus sub-surface) and fifteen leaf samples, from the plant of the same soil spot, were collected randomly from each study site. The samples were brought to the laboratory, department of soil science, SAU, Tandojam, Sindh, Pakistan for analysis. In soil major nutrients like $\mathrm{N}, \mathrm{P}, \mathrm{K}, \mathrm{Ca}, \mathrm{Mg}$, and minor nutrients like $\mathrm{Zn}, \mathrm{CO}_{3}^{-}, \mathrm{HCO}_{3}^{-}$ and $\mathrm{Cl}^{-}$and Organic Matter (OM), Electrical Conductivity (EC), $\mathrm{pH}$ and lime $\left(\mathrm{CaCO}_{3}\right)$ contents were tested.

\section{Result and Discussion}

Soil textural class analysis is showed (Table 1) the surface and subsurface soils of coastal areas of Sindh were heavy in texture. Same result results were also reported [7] [9] that soils of coastal areas are alluvial soils and contain high quantity of clay particles.

Figures 1-4 showed the results of $\left(\mathrm{EC}, \mathrm{pH}, \mathrm{OM}\right.$ and $\left.\mathrm{CaCO}_{3}\right)$ and described that $\mathrm{EC}$ was non-saline, $\mathrm{pH}$ was medium to strongly alkaline in reaction, organic matter was medium to adequate in content and lime content was 


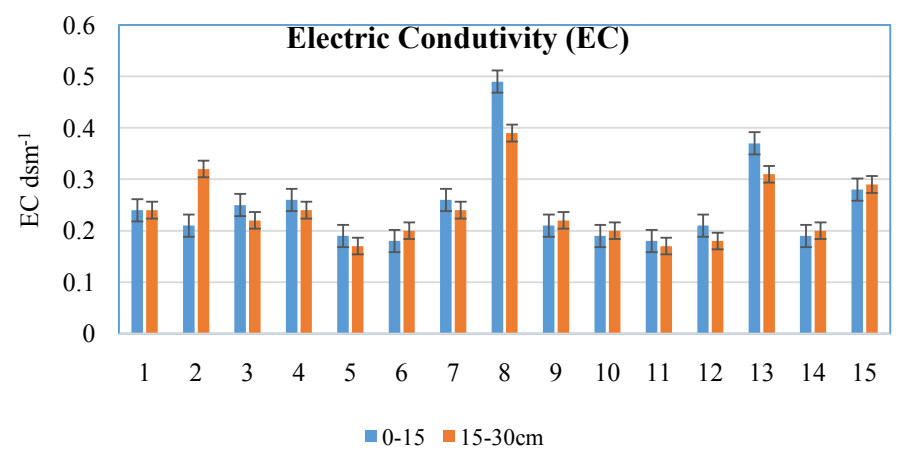

Figure 1. Shows results of EC $\left(\mathrm{d} \cdot \mathrm{sm}^{-1}\right)$ in soils of coastal areas of Sindh, Pakistan.

pH

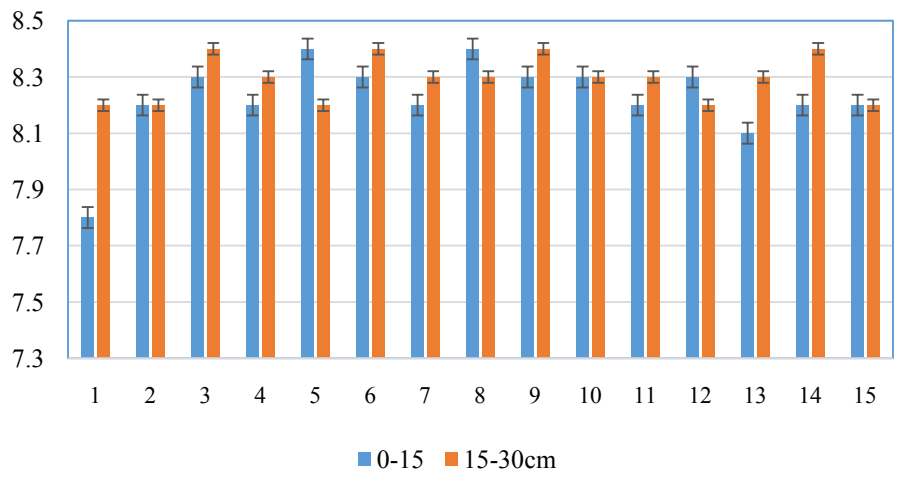

Figure 2. Shows results of $\mathrm{pH}$ in soils of coastal areas of Sindh, Pakistan.

Organic Matter

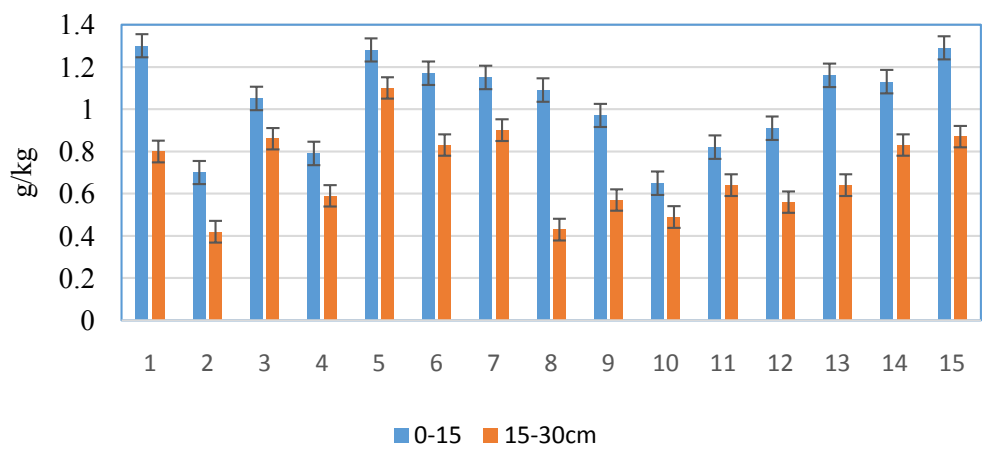

Figure 3. Shows results of organic matter in soils of coastal areas of Sindh, Pakistan.

Calcium Carbonate

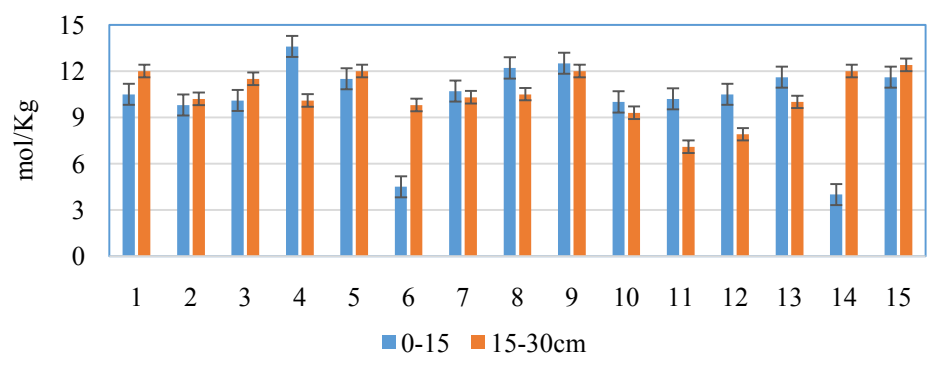

Figure 4. Shows results of calcium carbonate in soils of coastal areas of Sindh, Pakistan. 
moderately calcareous in nature. This might be due to the fact that banana cultivation requires more water which causes leaching of salts and in the end soils becomes non-saline in nature. This phenomenon may also be occurred due to coastal areas near to sea, use of excessive farm yard manure (FYM) and fertilizers and presence of dolomite and calcite mineral as a parent material respectively.

Figures 5-7 showed the results for total nitrogen (TN) aavailable phosphorous (AP) and exchangeable potassium (EP). Analysis showed that $\mathrm{N}$ were poor to medium in total $\mathrm{N}$ at both the soil layers, Phosphorous analysis showed low to optimum in available $\mathrm{P}$ and optimum in exchangeable potassium.

Figures 8-10 showed the analysis of calcium, magnesium and available zinc which described that mostly soils were medium in exchangeable potassium and magnesium and deficiency in available zinc at both the soil layers.

Figure 11 and Figure 12 showed the analysis of bicarbonates and chlorides which described that most of the bicarbonates were present in minute quantities, whereas chlorides were dominates ion at both soil layers.

Figure 13 showed the analysis of NPK and Zn leaf concentrations of banana plants which described that most of $\mathrm{N}$ and available $\mathrm{Zn} \mathrm{mg} / \mathrm{kg}^{-1}$ were below whereas $\mathrm{P}$ and $\mathrm{K}$ were above the critical levels as suggested by [2] [3]. With an average value of $2.29 \%$ and $2.40 \%, 0.48 \%$ and $0.38 \%, 6.1 \%$ and $6.9 \%$ respectively.

Figure 14 and Figure 15 showed the analysis of $\mathrm{Ca}, \mathrm{Mg}$ and $\mathrm{Cl}$ concentrations of banana leaves which described that mostly $\mathrm{Ca}, \mathrm{Mg}$ and $\mathrm{Cl}$ ion were above the critical levels as suggested by [2] [3] with an average value of $0.68 \%$ and $0.75 \%, 0.67 \%$ and $0.77 \%, 0.83 \%$ and $0.836 \%$ respectively.

Total Nitrogen

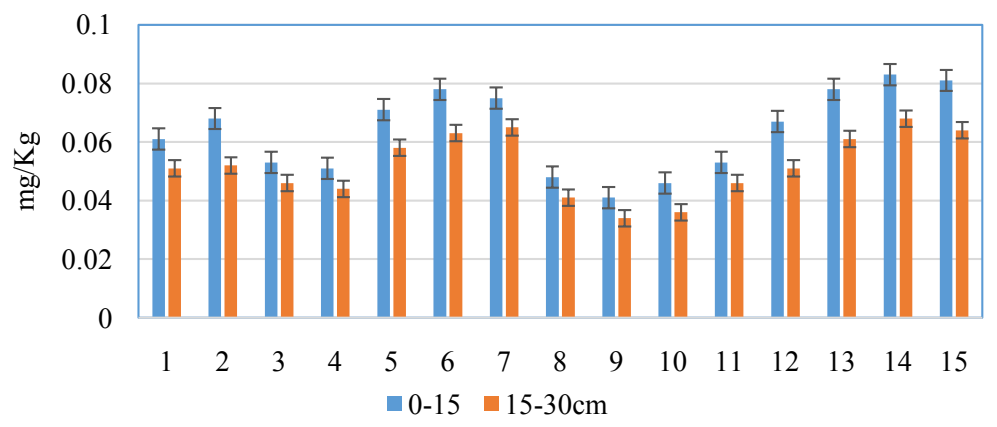

Figure 5. Shows results of total nitrogen in soils of coastal areas of Sindh, Pakistan.

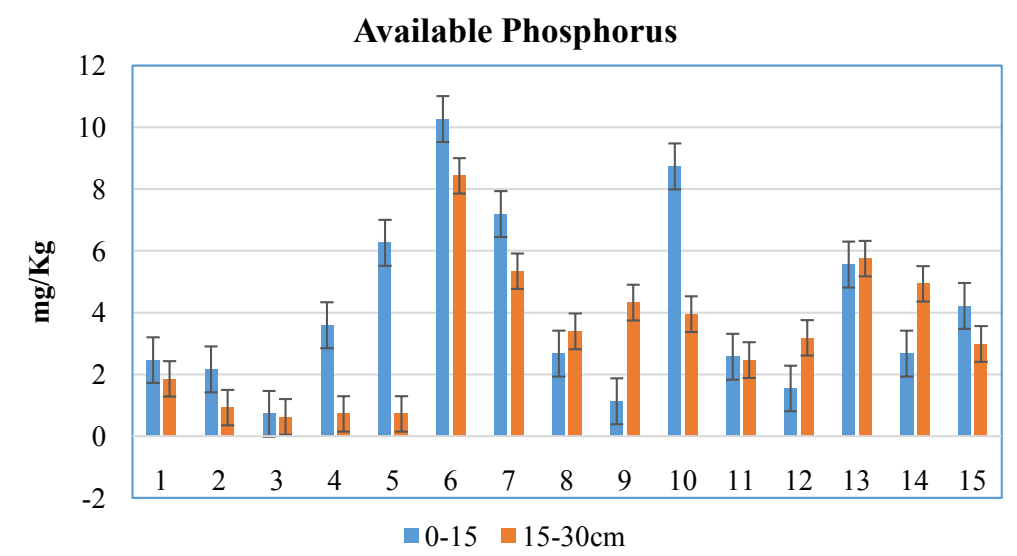

Figure 6. Shows results of available phosphorus in soils of coastal areas of Sindh, Pakistan.

Table 1. Particle size distribution and soil texture.

\begin{tabular}{cccccccc}
\hline \multicolumn{3}{c}{$\mathbf{0 ~} \mathbf{- 1 5} \mathbf{~ c m}$} & \multicolumn{3}{c}{$\mathbf{1 5} \mathbf{- 3 0} \mathbf{~ c m}$} \\
\hline Sand $\%$ & Silt $\%$ & Clay $\%$ & Textural class & Sand $\%$ & Silt $\%$ & Clay \% & Textural class \\
\hline 21.9 & 35.3 & 42.8 & Clay loam & 22.3 & 35.9 & 41.2 & Silty clay \\
\hline
\end{tabular}




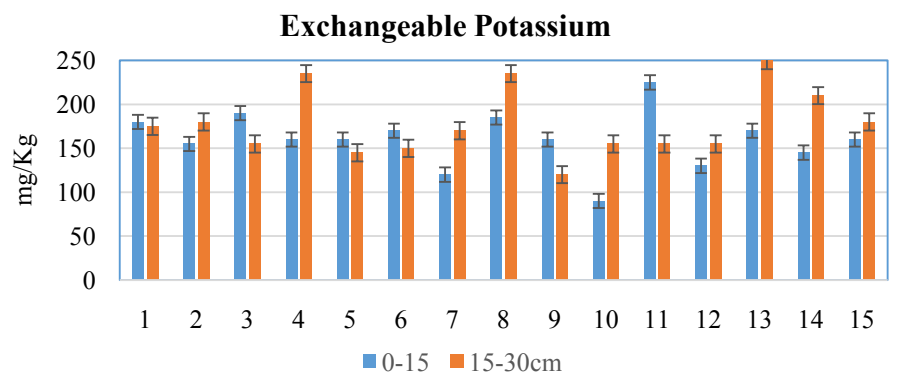

Figure 7. Shows results of exchangeable potassium in soils of coastal areas of Sindh, Pakistan.

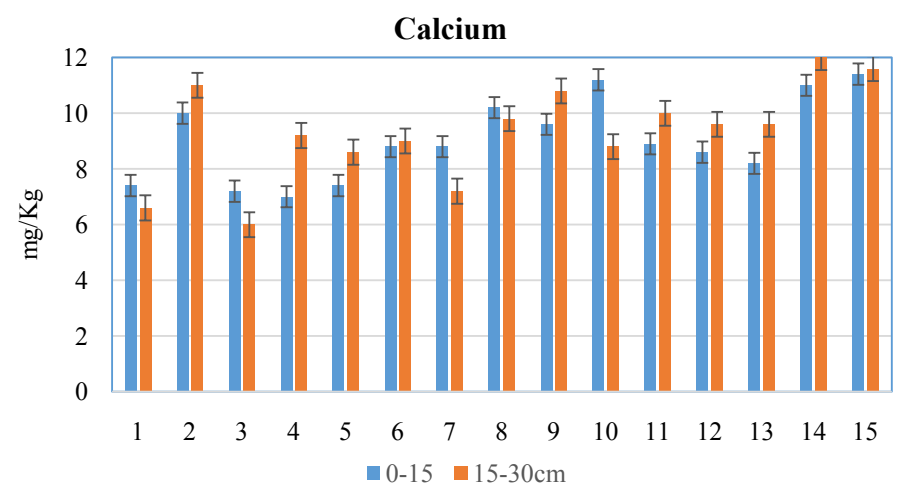

Figure 8. Shows results of $\mathrm{Ca}$ in soils of coastal areas of Sindh, Pakistan.

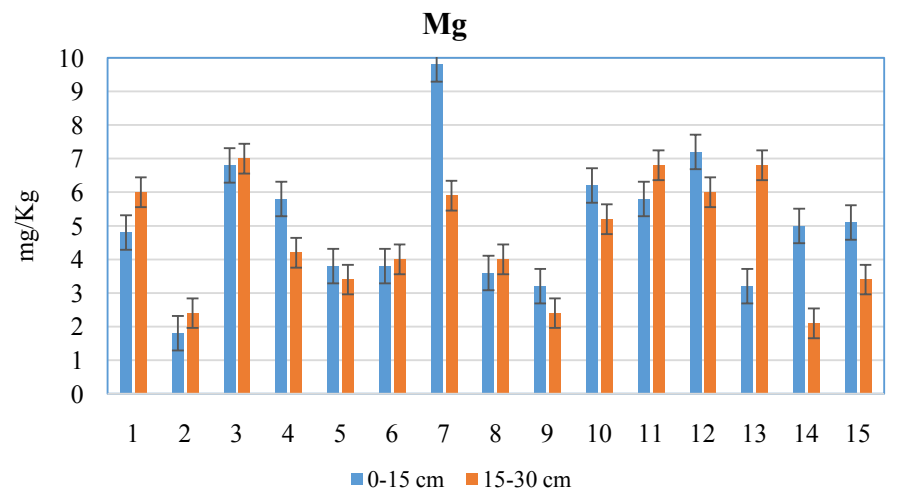

Figure 9. Shows results of $\mathrm{Mg}$ in soils of coastal areas of Sindh, Pakistan.

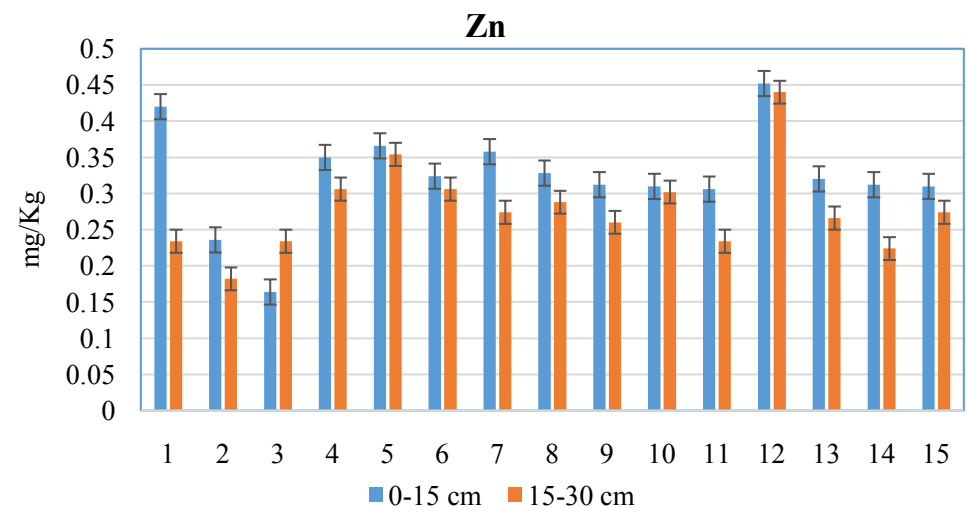

Figure 10. Shows results of $\mathrm{Zn}$ in soils of coastal areas of Sindh, Pakistan. 


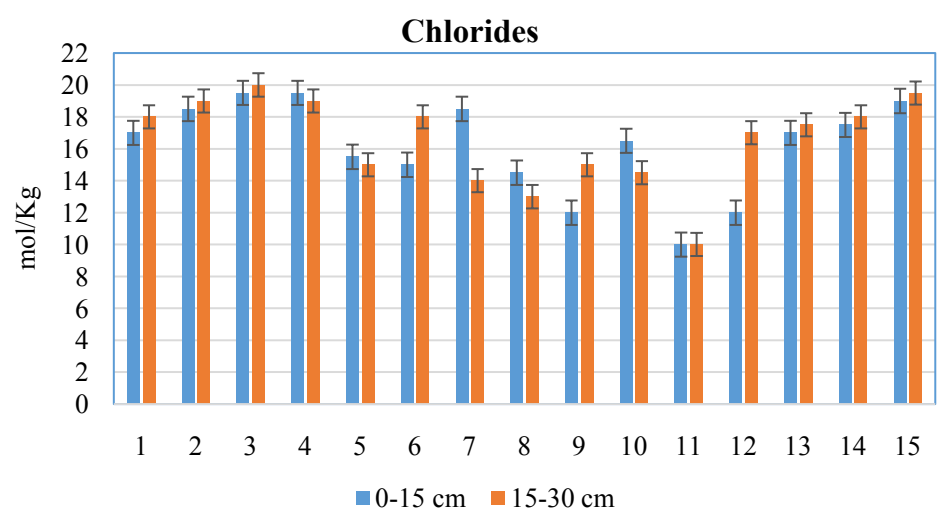

Fgure 11. Shows results of chlorides in soils of coastal areas of Sindh, Pakistan.

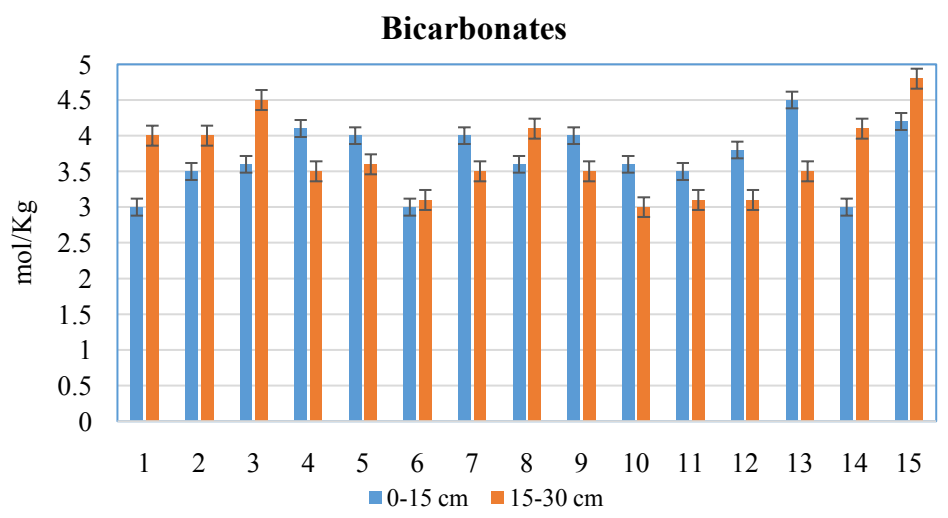

Figure 12. Shows results of bicarbonate in soils of coastal areas of Sindh, Pakistan.

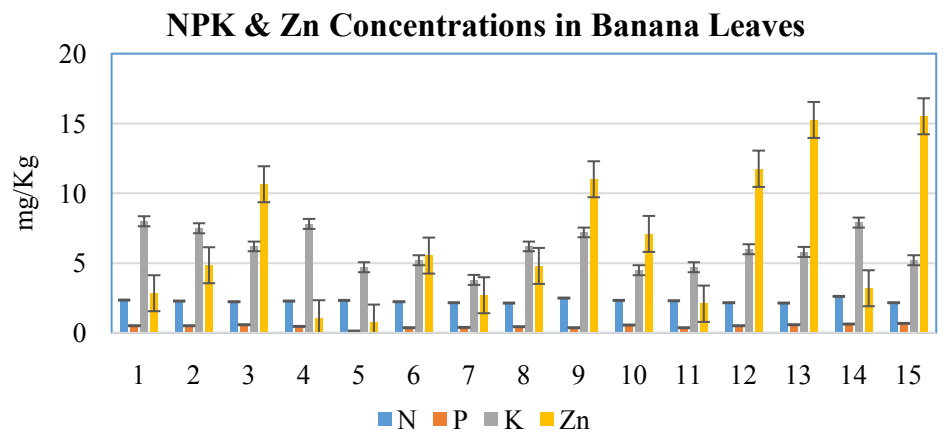

Figure 13. Shows results of NPK and $\mathrm{Zn}$ in banana leaves.

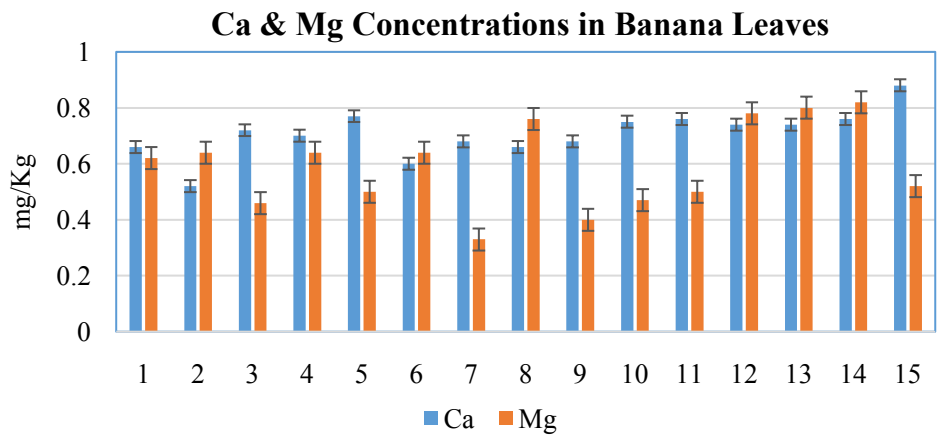

Figure 14. Shows results of $\mathrm{Ca}$ and $\mathrm{Mg}$ in banana leaves. 


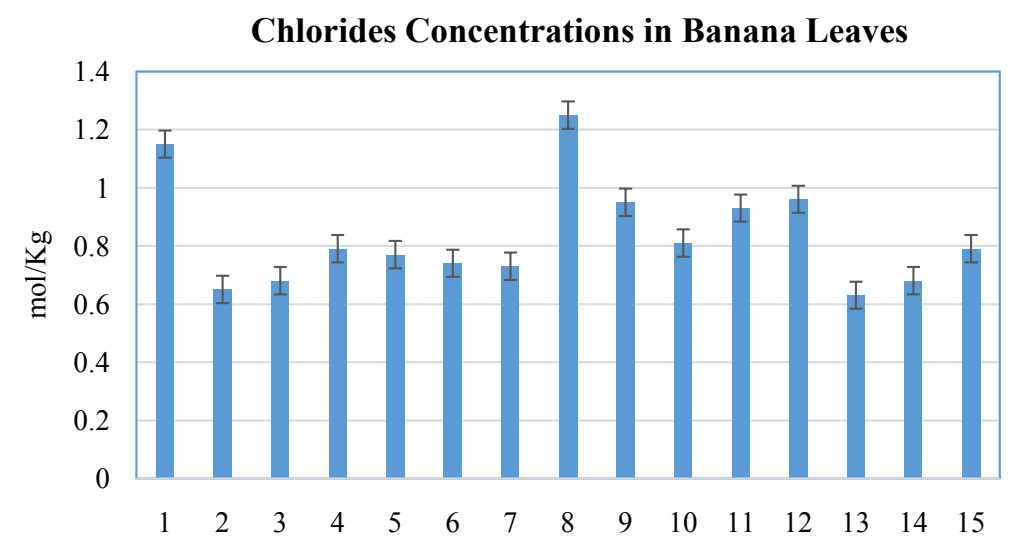

Figure 15. Shows results of chlorides in banana leaves.

\section{Conclusion}

This study assessed that soils of Sindh coastal area were heavily compacted in structure which might affect the internal drainage of soil. Results showed that physicochemical properties of surface and sub-surface soils layers were non-saline, medium alkaline and moderately calcareous in nature. Concentrations of nitrogen and zinc were remained below critical levels of soil standards, whereas phosphorus, potassium, manganese and chloride ions were recorded above the critical limits. This study recommends that fertilizers dosage 20 tons $/ \mathrm{ha}^{-1}$ of farmyard manure should be provided to deficient soils of nitrogen and phosphorous to get maximum banana yield.

\section{References}

[1] FAO (1980) Soil and Plant Testing Analyzing Bulletin. 38/1, Food and Agriculture Organization of United Nations, Rome.

[2] Lahav, E. (1972) Factors Influencing the Potassium Content of the Third Leaf of the Banana Sucker. Fruits, 27, 855590.

[3] Turner, D.W., Korawis, C. and Robson, A.D. (1989) Soil Analysis and Its Relationship with Leaf Analysis and Banana Yield with Special Reference to a Study at Carnarvon, Western Australia. Vol. 44, EDP Sciences, Les Ulis, France, 193-203.

[4] MINFAL (2001) Agricultural Statistics of Pakistan. Ministry of Food, Agriculture, Livestock, Economic Wing, Islamabad.

[5] Bouyoucos, G.J. (1962) Hydrometer Method Improved for Making Particle-Size Analysis of Soils. Agronomy Journal, 53, 464-465. http://dx.doi.org/10.2134/agronj1962.00021962005400050028x

[6] Olsen, S.R., Cole, C.V., Watanabe, F.S. and Dean, L.A. (1954) Estimation of Available Phosphorus in Soils by Extraction with Sodium Bicarbonate.

[7] Baloch, A.H. (1998) Micronutrient of Banana in Tehsil Hyderabad. M.Sc. (Agri) Hons Thesis Submitted to Department of Soil Science, Sindh Agriculture University, Tando Jam.

[8] Korai, A.A. (2001) Study on NPK Status in Soils and Banana Plants of Districts Nawabshah. M.Sc. (Agri) Hons Thesis Submitted to Department of Soil Science, Sindh Agriculture University, Tando Jam.

[9] Turner, D.W. and Barkus, B. (1977) A Comparison of Leaf Sampling Methods in Bananas. Fruits, 32, 725-730. 